\title{
A Review of the Traditional Uses, Phytochemistry and Biological Activities of the Genus Santolina
}

Authors

Rosa Tundis, Monica Rosa Loizzo

\author{
Affiliation \\ Department of Pharmacy, Health and Nutritional Sciences, \\ University of Calabria, Rende (CS), Italy
}

Key words

Santolina, Asteraceae, ethnobotany, phytochemicals, biological activities

$\begin{array}{ll}\text { received } & \text { November 15, } 2017 \\ \text { revised } & \text { February 5, 2018 } \\ \text { accepted } & \text { February 16, } 2018\end{array}$

Bibliography

DOI https://doi.org/10.1055/a-0585-6153

Published online March 8, 2018 | Planta Med 2018; 84: 627-

637 ㄷ Georg Thieme Verlag KG Stuttgart · New York | ISSN 0032-0943

\author{
Correspondence \\ Prof. Rosa Tundis \\ Department of Pharmacy, Health and Nutritional Sciences, \\ University of Calabria \\ Via P. Bucci - Edificio polifunzionale, 87036 Rende (CS), Italy \\ Phone: + 39984493246 , Fax: + 3998449310774 \\ rosa.tundis@unical.it
}

\begin{abstract}
The genus Santolina is a taxonomically complex group of plant species widely distributed in the Mediterranean flora and used in traditional medicine since ancient times for their biological properties, including antimicrobial, anti-inflammatory, antispasmodic, digestive, and analgesic activities. Phytochemical investigations of Santolina species have revealed the presence of terpenoids as the main bioactive constituents of the genus. Coumarins and flavonoids were also identified. This review deals, for the first time, with information on the traditional uses, chemical profile, and biological properties of plants of the genus Santolina in order to provide input for future research prospects.
\end{abstract}

$\begin{array}{ll}\text { ABBREVIATIONS } \\ \text { GPT } & \text { glutamate pyruvate transaminase } \\ \text { HD } & \text { hydrodistillation } \\ \text { HSV-1 } & \text { herpes simplex type } 1 \\ \text { HSV-2 } & \text { herpes simplex type } 2 \\ \text { MIC } & \text { minimum inhibitory concentration } \\ \text { MPLC } & \text { medium-pressure liquid chromatography } \\ \text { NF- } K \text { B } & \text { nuclear factor-kappa B } \\ \text { PLA1 } & \text { phospholipase A1 } \\ \text { PLA2 } & \text { phospholipase A2 } \\ \text { SFE } & \text { supercritical fluid extraction }\end{array}$

\section{Introduction}

The Santolina genus (family Asteraceae, tribe Anthemideae) comprises species widely distributed in the Mediterranean area. The Plant List includes 103 scientific plant names of species of this genus. However, of these, only 20 are accepted species names (San- tolina africana Jord. \& Fourr., Santolina benthamiana Jord. \& Fourr., Santolina canescens Lag., Santolina chamaecyparissus L., Santolina corsica Jord. \& Fourr., Santolina decumbens Mill., Santolina elegans Boiss. ex DC., Santolina etrusca (Lacaita) Marchi \& D’Amato, Santolina insularis (Gennari ex Fiori) Arrigoni, Santolina magonica Romo, Santolina melidensis Rodr.Oubiña \& S.Ortiz, Santolina neapolitana Jord. \& Fourr., Santolina oblongifolia Boiss., Santolina pectinata Lag., Santolina pinnata Viv., Santolina rosmarinifolia L., Santolina semidentata Hoffmanns. \& Link, Santolina tincloria “Molina”, Santolina villosa Mill., and Santolina virens Mill.). It is a taxonomically complex genus consisting of plant species whose classification has been revised several times.

S. chamaecyparissus L., S. pectinata Lag., and Santolina viridis W. are the most widespread [1]. With increasing interest in bioactive secondary metabolites from Santolina spp., several studies related to the investigation of the phytochemical composition and biological properties of species from this genus have been carried out. In recent decades, phytochemical studies have discovered the presence of terpenoids, particularly eudesmane and germacrane sesquiterpenoids, chrysanthemane monoterpenoids [2,3], dammarane-type triterpenes [4], flavonoids [5,6], and coumarins 
- Table 1 Ethnomedicinal uses of Santolina species.

\begin{tabular}{|c|c|c|c|c|c|}
\hline Santolina species & Local name & Traditional uses & Part used & Country & Ref. \\
\hline S. chamaecyparissus & $\begin{array}{l}\text { lavender cotton, gray san- } \\
\text { tolina }\end{array}$ & $\begin{array}{l}\text { antispasmodic, digestive, analgesic, } \\
\text { anti-inflammatory, antiseptic, stimulant, } \\
\text { and antimicrobial; to treat dermatitis }\end{array}$ & inflorescence & $\begin{array}{l}\text { Mediterranean } \\
\text { area, India }\end{array}$ & {$[11-14]$} \\
\hline $\begin{array}{l}\text { S. chamaecyparissus } \\
\text { subsp. squarrosa }\end{array}$ & $\begin{array}{l}\text { manzanilla, manzanilla de } \\
\text { monte, manzanilla basta, } \\
\text { manzanilla de burro }\end{array}$ & $\begin{array}{l}\text { to treat ophthalmological problems, } \\
\text { headache, belly pain, stomach problems, } \\
\text { and as digestive and depurative }\end{array}$ & inflorescence & Spain & {$[15,16]$} \\
\hline S. corsica & crespolina di Corsica & intestinal vermifuge, parasite repellent & inflorescence & Italy & {$[19,20]$} \\
\hline S. etrusca & canfora & antiparasitic & aerial parts & Italy & {$[21]$} \\
\hline S. insularis & $\begin{array}{l}\text { crespolina maggiore, san- } \\
\text { tolina, crespolina sarda }\end{array}$ & vermifuge and to repel insects & inflorescence & Italy & {$[19]$} \\
\hline S. insularis & crespolina insulare & sedative, febrifuge, and antitussive & leaves & Italy & {$[18]$} \\
\hline S. neapolitana & $\begin{array}{l}\text { green santolina, crespolina } \\
\text { napoletana }\end{array}$ & cough suppressant & aerial parts & Italy & {$[17]$} \\
\hline S. oblongifolia & manzanilla de Gredos & anti-inflammatory and digestive & inflorescence & Spain & {$[7]$} \\
\hline S. rosmarinifolia & green lavender cotton & $\begin{array}{l}\text { antipyretic, antihypertensive, hepato- } \\
\text { protective, and anti-inflammatory }\end{array}$ & flower heads & Spain & {$[22,26]$} \\
\hline
\end{tabular}

$[6,7]$ in plant species of this genus. The literature data revealed that Santolina species show various biological activities, including antibacterial, antifungal, antiviral, anti-inflammatory, cytotoxic, and hepatoprotective effects $[2,5,8-11]$.

The aim of this review is to provide a complete overview of existing knowledge on the traditional uses, chemical constituents, and biological properties of plant species from the Santolina genus.

The available information on this genus was collected from scientific databases up until November 2017. The following electronic databases were used: PubMed, SciFinder, Science Direct, Scopus, Web of Science, Wiley, ACS, Springer, and Google Scholar. The search terms used for this review included Santolina, Santolina chamaecyparissus, Santolina insularis, Santolina corsica, Santolina oblongifolia, Santolina canescens, Santolina neapolitana, Santolina pinnata, Santolina pectinata, Santolina rosmarinifolia, Santolina etrusca, Santolina semidentata, Santolina tincloria, Santolina villosa, Santolina virens, phytochemical composition, essential oils, sesquiterpenes, phenols, flavonoids, coumarins, traditional uses, activity, pharmacology, and toxicity. No limitations were set for languages. "The Plant List" (www.theplantlist.org) was used to validate the scientific names of the Santolina species. Seventy-five potentially relevant records were found, from which seven were excluded after screening the titles or abstracts.

From the available literature, two species, namely, S. chamaecyparissus and S. insularis, have been the most investigated. S. corsica, S. oblongifolia, S. canescens, S. rosmarinifolia, and S. etrusca have also been phytochemically and biologically studied. S. pectinata and S. semidentata were investigated for the chemical composition of their essential oil, but no biological studies were described.

Critical evaluation of biological studies in terms of their relation to the chemical profile is highlighted. Available information on these species allows us to provide the scientific basis for future research studies and to explore their potential therapeutic use.

\section{Traditional Uses}

For a long time, several plant species have been used for medicinal purposes. Among Santolina species, S. chamaecyparissus, S. etrusca, S. insularis, S. neapolitana, and S. oblongifolia have been reported in traditional medicine. A summary of their traditional use is presented in $>$ Table $\mathbf{1}$. S. chamaecyparissus has been inserted in the Ayurvedic system of medicine in India for the treatment of liver diseases. Moreover, the yellow inflorescences of S. chamaecyparissus are widely used in Mediterranean traditional medicine for their analgesic, anti-inflammatory, antispasmodic, antiseptic, and antimicrobial properties [11,12]. Moreover, this plant, commonly called "lavender cotton" or "gray santolina", is employed for the treatment of numerous kinds of dermatitis, as a stimulant, and as a stomachic $[13,14]$. In the traditional medicine of Spain, S. chamaecyparissus subsp. squarrosa was used as a substitute for Artemisia granatensis, "manzanilla real", for the treatment of ophthalmological problems, headache, belly pain, stomach problems, and as a digestive and depurative $[15,16]$. This species is locally named "manzanilla de monte", "manzanilla basta”, and "manzanilla de burro" [16].

Savo et al. [17] reported the use of S. neapolitana (= S. pinnata subsp. neapolitana) against cough in the Amalfi Coast (Campania, Southern Italy). A decoction of the leaves of S. insularis, known in Italy as "crespolina maggiore", has been used as a sedative, febrifuge, and antitussive [18]. The whole plant was used as an intestinal vermifuge against horse strongyloidiasis and as a parasite repellent $[19,20]$. Another Santolina species used in Italy as an intestinal vermifuge and parasite repellent is S. corsica $[19,20]$. S. etrusca ("canfora") is known in Italy for its traditional uses. This is an endemic species growing in the gravel beds of rivers, clayey, and arid hills, and is found exclusively in Central Italy, particularly in Northern Latium, Tuscany, and Umbria. Its antiparasitic activity has been reported [21]. In the traditional medicine of Spain, S. oblongifolia, known as "manzanilla de Gredos”, is used as a digestive 
- Table 2 The main volatiles of the essential oils from Santolina species.

\begin{tabular}{|c|c|c|c|}
\hline Plant species & Country & Main compounds & Reference \\
\hline S. africana & Algeria & acenaphtane, calarene, ocimene & {$[48]$} \\
\hline S. africana & Algeria & $\beta$-pinene, 1,8-cineol, myrcene, curcumene, spathulenol & [49] \\
\hline S. canescens & Spain & santolindiacetylene, camphor, myrcene & [51] \\
\hline S. canescens & Spain & camphor, 1,8-cineole, $\beta$-pinene, myrcene, sabinene, ar-curcumene & [45] \\
\hline S. chamaecyparissus & France & artemisia ketone, myrcene & [33] \\
\hline S. chamaecyparissus & Turkey & artemisia ketone, camphor, $\beta$-phellandrene, $\alpha$-bisabolol & [34] \\
\hline S. chamaecyparissus & Tunisia & 1,8-cineole, $\beta$-eudesmol, terpinene-4-ol, $\gamma$-cadinene & [35] \\
\hline S. chamaecyparissus & India & artemisia ketone, 1,8-cineole, myrcene, germacrene d & [36] \\
\hline S. chamaecyparissus & Syria & artemisia ketone, $\alpha$-amorphene, $\beta$-phellandrene, $\beta$-myrcene & [37] \\
\hline S. chamaecyparissus & Algeria & camphor, cubenol, p-cymene, sabinene & [38] \\
\hline S. chamaecyparissus & Italy & artemisia ketone, $\beta$-phellandrene, myrcene, sabinene & [39] \\
\hline S. chamaecyparissus & Spain & 1,8-cineole, camphor, borneol, terpinen-4-ol, terpinolene & [40] \\
\hline S. corsica & Italy & camphor, borneol, aromadendrene, muurolene & {$[20]$} \\
\hline S. corsica & Italy & artemisia ketone, $\beta$-phellandrene, myrcene, santolinatriene & [41] \\
\hline S. corsica & Italy & myrcene, santolinatriene, $\beta$-phellandrene, $\beta$-pinene, isolyratol & [8] \\
\hline S. etrusca & Italy & 1,8-cineole, $\beta$-pinene, myrcene, sabinene, trans-pinocarveol & [48] \\
\hline S. insularis & Italy & $\begin{array}{l}\text { 3,3,6-trimethyl-1,5-heptadien-4-one, } 10 \text {-h-cyclopropyl-1,1,7-trimethyl-4- } \\
\text { methylen-decahydro azulene, cineole, camphene }\end{array}$ & {$[20]$} \\
\hline S. insularis & Italy & myrcene, $\beta$-phellandrene, trans- $\beta$-terpineol, ar-curcumene & [42] \\
\hline S. insularis & Italy & artemisia ketone, cis-chrysanthemol, myrcene, $\beta$-phellandrene & {$[43]$} \\
\hline S. ligustica & Italy & myrcene, 1,8-cineole, terpinen-4-ol, sabinene & [47] \\
\hline S. neapolitana & Italy & $\gamma$-muurolene, $\alpha$-pinene, borneol & [46] \\
\hline S. pectinata & Spain & $\beta$-eudesmol, nerolidol, spathulenol, $\alpha$-cadinol, $\gamma$-eudesmol, & [45] \\
\hline S. rosmarinifolia & Romania & $\beta$-eudesmol, 1,8-cineole, camphor, borneol, ar-curcumene & [52] \\
\hline $\begin{array}{l}\text { S. rosmarinifolia subsp. } \\
\text { rosmarinifolia }\end{array}$ & Spain & $\beta$-phellandrene, $\beta$-pinene, limonene, myrcene & {$[53]$} \\
\hline S. semidentata & Spain & $\beta$-eudesmol, nerolidol, spathulenol, $\alpha$-cadinol, $\mathrm{T}$-cadinol & [45] \\
\hline
\end{tabular}

sedative and tonic, and for the treatment of rheumatism and menstrual disorders [7]. This species is known for its mild flavor and sweetness, and for its beneficial effects on the digestive tract [7].

S. rosmarinifolia, known as "green lavender cotton", is a dwarf perennial shrub mainly distributed in the Iberian Peninsula and South France. S. rosmarinifolia flower heads (fresh or dried) are used in traditional preparations for their antihypertensive, anti-inflammatory, antipyretic, and hepatoprotective properties [22].

\section{Phytochemicals}

Phytochemical investigations on Santolina species revealed the presence of several classes of constituents. Eudesmane-type sesquiterpenes [23-27], germacrane-type sesquiterpenes [2,2326], dammarane-type triterpenes [4], acetylene heterocycles [4, $28,29]$, spiroketalenol ether-type acetylenes [4, 24, 27-29], flavonoids $[5,6]$, and coumarins $[6,7,27]$ have been identified as common secondary metabolites from the genus. Several Santolina species have been studied for their essential oil composition. S. chamaecyparissus is one of the most investigated Santolina spe- cies. A different chemical composition, depending on its origin, was evidenced by several researchers ( $\bullet$ Table 2$)[1,30-35]$. The $\mathrm{HD}$ of the flower heads of $S$. chamaecyparissus from Tunisia has allowed for obtaining an oil rich in 1,8-cineole (12.94\%), $\beta$-eudesmol (10.49\%), terpinene-4-ol (6.97\%), $y$-cadinene (6.55\%), spathulenol (5.80\%), camphor (5.27\%), germacrene D (5.03\%), and myrtenol (4.26\%) [35]. The oil of S. chamaecyparissus obtained by HD of the air-dried aerial parts collected in Turkey is characterized mainly by monoterpenes ( $81 \%$ of the total oil) [34]. Oxygenated monoterpenes predominated over the monoterpenes hydrocarbons. The main constituents are artemisia ketone (38.1\%), camphor (11.7\%), $\beta$-phellandrene (9.2\%), $\alpha$-bisalolol (6.6\%), and myrcene $(4.3 \%)$. Artemisia ketone is also the dominant constituent of the essential oil of S. chamaecyparissus from India [36]. Other abundant compounds are 1,8-cineole (15.6\%), myrcene (14.2\%), germacrene $D(8.8 \%)$, sabinene $(4.5 \%)$, and terpinin-4ol (2.9\%). Artemisia ketone (15.65\%) together with $\alpha$-amorphene (12.11\%), $\beta$-phellandrene (10.63\%), $\beta$-myrcene $(7.42 \%)$, and nootkatone $(6.97 \%)$ were identified as the main compounds of the oil from Syria [37]. The composition of this oil greatly differed from the oil of S. chamaecyparissus collected in Algeria [38]. In 
fact, Djeddi et al. [38] showed camphor (31.1\%), cubenol (17.0\%), p-cymene (8.3\%), and sabinene $(4.0 \%)$ as the most abundant constituents. Instead, as in the oil from India, the essential oil of S. chamaecyparissus collected in France [33] and in Italy [39] showed artemisia ketone as the dominant constituent. Monoterpene hydrocarbons (29.5\%) and oxygenated monoterpenes $(36.81 \%)$ are the main classes of the essential oil of S. chamaecyparissus from Italy [39], in which, besides artemisia ketone (28.24\%), the other abundant constituents are $\beta$-phellandrene (12.78\%), myrcene (8.02\%), and sabinene (7.65\%).

Grosso et al. [40] compared the essential oil of S. chamaecyparissus (Spain) obtained by SFE with the essential oil obtained by $\mathrm{HD}$, and found 1,8-cineole to be the most abundant component (7-48\% and $25-30 \%$ for SFE and HD, respectively), followed by camphor (8-14 and 7-9\% for SFE and HD, respectively), borneol (2-11 and 7-8\% for SFE and HD, respectively), terpinen-4-ol (1-4 and $6-7 \%$ for SFE and HD, respectively), and terpinolene (1-7 and $1-4 \%$ for SFE and HD, respectively). In previous studies, some S. chamaecyparissus subspecies from Spain were described to contain 1,8-cineole (2-18\%), artemisia ketone (0.1-28\%), camphor (trace-43\%), borneol (1-28\%), copaenol (trace-15\%), allo-aromadendrene $(19 \%)$, and cubenol $(1-17 \%)$ as major constituents $[12,30]$. Three works reported the chemical profile of the essential oil from S. corsica, a perennial shrub growing in the rocky places of Corsica (France) and Sardinia (Italy). The essential oil of S. corsica collected in Corsica was dominated by monoterpene hydrocarbons. Artemisia ketone (20.0\%), $\beta$-phellandrene (14.4\%), myrcene (11.7\%), santolinatriene (8.2\%), 1,8-cineole (4.4\%), and $\beta$-pinene (4.3\%) were identified as the main compounds [41].

Except for artemisia ketone, found with a percentage of $0.1 \%$, myrcene (34.6\%), santolinatriene (13.5\%), and $\beta$-phellandrene (11.7\%) were found to be the most abundant compounds in the Corsican essential oil in a study by Liu et al. [8]. Otherwise, the essential oil from S. corsica collected in Sardinia (Italy) showed camphor (18.5\%), artemisia ketone (12.97\%), borneol (7.41\%), aromadendrene $(5.55 \%)$, and muurolene $(4.63 \%)$ as the main constituents [20]. 3,3,6-Trimethyl-1,5-heptadien-4-one (21.18\%), 10-H-cyclopropyl-1,1,7-trimethyl-4-methylendecahydro azulene (12.7\%) cineole $(9.01 \%)$, camphene $(8.47 \%)$, bornyl acetate (6.35\%), and borneol (4.23\%) were the main constituents of the essential oil of S. insularis collected in Sardinia (Italy) [20]. A different composition with myrcene $(14.8-17 \%), \beta$-phellandrene (8$9 \%)$, ar-curcumene (6-10\%), and trans- $\beta$-terpineol (5-6\%) as the main constituents was reported by Cherchi et al. [42] for the essential oils obtained from the aerial parts of $S$. insularis collected in the same Italian region (Sardinia).

More recently, Gnavi et al. [43] studied four S. insularis samples from Sardinia (Italy). Artemisia ketone, cis-chrysanthemol, myrcene, $\beta$-phellandrene, $\beta$-pinene, and santolinatriene were identified as the most abundant constituents. However, different percentages of these main compounds were reported. This work showed remarkable chemical variation in the terpenoid profile and a consistent genomic difference in the 5S-rRNA spacer regions that led to identifying four chemotypes of $S$. insularis grouped into two ecotypes. The analysis of these data showed a high variability in the composition and content of monotepenes and sesquiterpenes of $S$. insularis essential oils from the same geo-

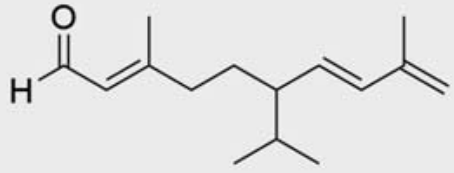

1

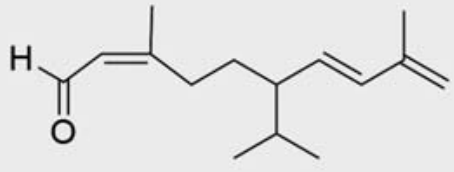

2

- Fig. 1 Chemical structures of isolated compounds 1 and 2 from S. corsica.

graphical area. Two isomeric irregular sesquiterpenes, 3,9-dimethyl-6-isopropyl-2(E),7(E),9-decatrienal (1) and 3,9-dimethyl6-isopropyl-2(Z),7(E),9-decatrienal (2), were isolated from the essential oil obtained by HD from the leaves of $S$. corsica (France) ( $\triangleright$ Fig. 1 and Table 3) [44]. The oil was subjected to flash column chromatography on silica gel, affording a nonpolar and a polar fraction. The polar fraction was purified by column chromatography on silica gel using pentane with increasing amounts of diethyl oxide as the eluent. Compounds 1 and 2 were isolated from subfractions using pentane/diethyl ether (95/5) as the eluent. Their structure was elucidated by using 1D and 2D NMR spectroscopy. The essential oil of $S$. pectinata contained $\beta$-eudesmol, nerolidol, spathulenol, $\alpha$-cadinol, $\gamma$-eudesmol, and elemol as the major constituents [45]. The essential oil of $S$. semidentata, an endemic species of Spain, was characterized by the presence of $\beta$-eudesmol, nerolidol, spathulenol, $\alpha$-cadinol, $T$-cadinol, $\gamma$-eudesmol, and elemol as the major components [45].

The essential oil of $S$. neapolitana obtained by HD from aerial parts collected in Italy with a yield of $0.30 \%(\mathrm{v} / \mathrm{w})$ was characterized by 41 constituents [46]. $\gamma$-Muurolene (31.9\%), $\alpha$-pinene (15.5\%), and borneol (9.4\%) were the most abundant compounds. Myrcene (12.0\%), 1,8-cineole (11.1\%), terpinen-4-ol (9.9\%), and sabinene $(6.7 \%)$ were the main constituents of the essential oil of Santolina ligustica aerial parts [47]. S. ligustica is an endemic Santolina species that grows in Eastern Liguria (Italy), generally on ophiolitic substrates. Other compounds found in good amounts were myrtenol (4.7\%), $\gamma$-terpinolene $(4.3 \%), \beta$ pinene (4.2\%), and bisabolol (3.1\%).

Flamini and Cioni [48] evaluated the seasonal variation of the components of the essential oil of inflorescences and fertile and sterile branches of another Santolina species from Italy, S. etrusca. The obtained results showed that the extraction yields generally increased from November to June, while decreasing in the months of August and September. Taking into account the variability of the oil during the whole year, the most abundant compounds belong to the class of monoterpene hydrocarbons, mainly, $\beta$-pinene, myrcene, and sabinene, and to the class of oxygenated monoterpenes, mainly 1,8-cineole. Twenty-six compounds characterized 
- Table 3 Isolated compounds from Santolina species.

\begin{tabular}{|c|c|c|c|}
\hline & Compound name & Plant & $\begin{array}{l}\text { Molecular formula, } \\
\text { molecular weight }\end{array}$ \\
\hline 1 & 3,9-dimethyl-6-isopropyl-2(E),7(E),9-decatrienal & S. insularis & $\mathrm{C}_{15} \mathrm{H}_{24} \mathrm{O}, 220.36$ \\
\hline 2 & 3,9-dimethyl-6-isopropyl-2(Z),7(E),9-decatrienal & S. insularis & $\mathrm{C}_{15} \mathrm{H}_{24} \mathrm{O}, 220.36$ \\
\hline 3 & apigenin & S. oblongifolia, S. pinnata & $\mathrm{C}_{15} \mathrm{H}_{10} \mathrm{O}_{5}, 270.24$ \\
\hline 4 & chrysoeriol & S. pinnata & $\mathrm{C}_{16} \mathrm{H}_{12} \mathrm{O}_{6}, 300.26$ \\
\hline 5 & luteolin & S. oblongifolia, S. pinnata & $\mathrm{C}_{15} \mathrm{H}_{10} \mathrm{O}_{6}, 286.24$ \\
\hline 6 & luteolin-7-glucoside & S. pinnata & $\mathrm{C}_{21} \mathrm{H}_{20} \mathrm{O}_{11}, 448.38$ \\
\hline 7 & kaempferol & S. pinnata & $\mathrm{C}_{15} \mathrm{H}_{10} \mathrm{O}_{6}, 286.24$ \\
\hline 8 & pectolinarigenin & S. pinnata & $\mathrm{C}_{23} \mathrm{H}_{24} \mathrm{O}_{11}, 476.43$ \\
\hline 9 & nepetin & S. pinnata & $\mathrm{C}_{16} \mathrm{H}_{12} \mathrm{O}_{7}, 316.26$ \\
\hline 10 & scopoletin & S. oblongifolia, S. pinnata & $\mathrm{C}_{10} \mathrm{H}_{8} \mathrm{O}_{4}, 192.17$ \\
\hline 11 & fraxetin & S. pinnata & $\mathrm{C}_{10} \mathrm{H}_{8} \mathrm{O}_{5}, 208.17$ \\
\hline 12 & $1 \alpha, 10 \beta$-epoxy- $7 \alpha \mathrm{H}$-germacr-4(15)-ene-2 $\beta, 5 \alpha, 6 \beta$-triol & S. pinnata subsp. neapolitana & $\mathrm{C}_{15} \mathrm{H}_{26} \mathrm{O}_{4}, 270.36$ \\
\hline 13 & $4 \beta, 5 \alpha$-epoxy-7 $\alpha \mathrm{H}$-germacr-1(10)E-ene- $2 \beta, 6 \beta$-diol & S. pinnata subsp. neapolitana & $\mathrm{C}_{15} \mathrm{H}_{26} \mathrm{O}_{3}, 254.37$ \\
\hline 14 & $4 \beta, 5 \alpha$-epoxy- $7 \alpha \mathrm{H}$-germacr-1(10)E-ene-2$\beta, 6 \beta$-diol 2 -acetate & S. pinnata subsp. neapolitana & $\mathrm{C}_{17} \mathrm{H}_{28} \mathrm{O}_{4}, 296.40$ \\
\hline 15 & $7 \alpha \mathrm{H}$-germacra-1(10)E,4(15)-diene-2 $\beta, 5 \alpha, 6 \beta$-triol & S. pinnata subsp. neapolitana & $\mathrm{C}_{15} \mathrm{H}_{26} \mathrm{O}_{3}, 254.37$ \\
\hline 16 & $7 \alpha \mathrm{H}$-germacra-1(10)E,4(15)-diene-2 $\beta, 5 \alpha, 6 \beta$-triol 2-acetate & S. pinnata subsp. neapolitana & $\mathrm{C}_{17} \mathrm{H}_{28} \mathrm{O}_{4}, 296.40$ \\
\hline 17 & $(1 R, 2 R, 5 R, 6 R, 7 S, 10 S)$-eudesma-4(15)-en-1,2,6-triol & S. insularis & $\mathrm{C}_{15} \mathrm{H}_{26} \mathrm{O}_{3}, 254.37$ \\
\hline 18 & $(1 R, 2 S, 6 R, 7 S, 10 S)-1,2,6$-trihydroxyeudesma-4-en-3-one & S. insularis & $\mathrm{C}_{15} \mathrm{H}_{24} \mathrm{O}_{4}, 268.17$ \\
\hline 19 & $(1 R, 2 R, 7 S, 10 S)$-eudesma-3,5-dien-1,2-diol & S. insularis & $\mathrm{C}_{15} \mathrm{H}_{24} \mathrm{O}_{2}, 236.18$ \\
\hline 20 & $(2 R, 3 R, 4 R)$-5-chrysanthemen-1,4-diol & S. insularis & $\mathrm{C}_{10} \mathrm{H}_{18} \mathrm{O}_{2}, 170.25$ \\
\hline 21 & elegansidiol & S. elegans & $\mathrm{C}_{15} \mathrm{H}_{26} \mathrm{O}_{2}, 238.37$ \\
\hline 22 & $(4 E, 9 Z)-6 \beta$-acetoxy-7 $\alpha \mathrm{H}$-germacra-4,9-diene-l$\alpha, 2 \beta$-diol & S. chamaecyparissus subsp. squarrosa & $\mathrm{C}_{17} \mathrm{H}_{28} \mathrm{O}_{4}, 296.40$ \\
\hline 23 & 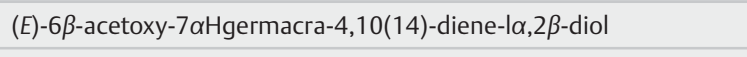 & S. chamaecyparissus subsp. squarrosa & $\mathrm{C}_{17} \mathrm{H}_{28} \mathrm{O}_{4}, 296.40$ \\
\hline 24 & $(E)-6 \beta$-acetoxy-7 $\alpha \mathrm{H}$-germacra-I(10),4-diene-2 $\beta$-ol & S. chamaecyparissus subsp. squarrosa & $\mathrm{C}_{17} \mathrm{H}_{28} \mathrm{O}_{3}, 280.40$ \\
\hline 25 & $6 \beta$-acetoxy- $5 \beta \mathrm{H}, 7 \alpha \mathrm{H}, 10 \beta \mathrm{Me}$-eudesm- 4 (15)-ene- $1 \alpha, 2 \beta$-diol & S. chamaecyparissus subsp. squarrosa & $\mathrm{C}_{17} \mathrm{H}_{28} \mathrm{O}_{4}, 296.40$ \\
\hline 26 & 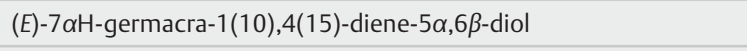 & S. rosmarinifolia subsp. canescens & $\mathrm{C}_{15} \mathrm{H}_{26} \mathrm{O}_{2}, 238.37$ \\
\hline 27 & $4 \beta, 5 \alpha$-epoxy-7 $\alpha \mathrm{H}$-germacr-10(14)-ene- $1 \beta, 6 \beta$-diol & S. rosmarinifolia subsp. canescens & $\mathrm{C}_{15} \mathrm{H}_{26} \mathrm{O}_{3}, 254.37$ \\
\hline 28 & (E)-6a,11-dihydroxy-7 $\alpha \mathrm{H}$-germacra-4,10(14)-dien-1-one & S. rosmarinifolia subsp. canescens & $\mathrm{C}_{15} \mathrm{H}_{24} \mathrm{O}_{3}, 252.35$ \\
\hline 29 & (E)-7 $\alpha \mathrm{H}$-germacra-4,10(14)-diene-1 $\alpha, 6 \alpha, 11$-triol & S. rosmarinifolia subsp. canescens & $\mathrm{C}_{15} \mathrm{H}_{26} \mathrm{O}_{3}, 254.37$ \\
\hline 30 & (E)-7 $\alpha \mathrm{H}$-germacra-4,10(14)-diene- $1 \beta, 6 \alpha, 11$-triol & S. rosmarinifolia subsp. canescens & $\mathrm{C}_{15} \mathrm{H}_{26} \mathrm{O}_{3}, 254.37$ \\
\hline 31 & (E)-7 $\alpha \mathrm{H}$-germacra-4,10(14)-diene- $1 \alpha, 6 \beta$-diol & S. rosmarinifolia subsp. canescens & $\mathrm{C}_{15} \mathrm{H}_{26} \mathrm{O}_{2}, 238.37$ \\
\hline 32 & $(1 E, 4 E)-7 \alpha \mathrm{H}$-germacra-1(10),4-dien-6 $\beta$-ol & S. rosmarinifolia subsp. canescens & $\mathrm{C}_{15} \mathrm{H}_{26} \mathrm{O}, 222.37$ \\
\hline 33 & shiromool & S. rosmarinifolia subsp. canescens & $\mathrm{C}_{15} \mathrm{H}_{26} \mathrm{O}_{2}, 238.19$ \\
\hline 34 & $(2 R, 5 R, 6 R, 7 S)$-germacra-1(10)E,4(15)-dien-5-hydroperoxy-2,6-diol & S. insularis & $\mathrm{C}_{15} \mathrm{H}_{26} \mathrm{O}_{4}, 270.36$ \\
\hline 35 & $\begin{array}{l}(2 R, 5 R, 6 R, 7 S) \text {-germacra-1(10)E,4(15)-dien-5-hydroperoxy-2,6-diol- } \\
\text { 2-acetate }\end{array}$ & S. insularis & $\mathrm{C}_{17} \mathrm{H}_{28} \mathrm{O}_{5}, 312.40$ \\
\hline 36 & $(1 R, 2 R, 4 S, 5 S, 6 R, 7 S)$-4,5-epoxygermacra-9Z-en-1,2,6-triol & S. insularis & $\mathrm{C}_{15} \mathrm{H}_{26} \mathrm{O}_{4}, 270.36$ \\
\hline 37 & $(3 R, 6 R, 7 S)$-3,6-dihydroxygermacra-4(5)E,10(14)-dien-1-one & S. insularis & $\mathrm{C}_{15} \mathrm{H}_{24} \mathrm{O}_{3}, 252.35$ \\
\hline
\end{tabular}

the essential oil obtained by the flowers of $S$. africana collected in Algeria. The oil showed monoterpene hydrocarbons (27.56\%) as the main class of constituents, followed by sesquiterpenes hydrocarbons (26.89\%). The main compounds were acenaphtane (25.23\%), calarene (21.54\%), and ocimene $17.44 \%$ [49]. Instead, Zaiter et al. [50], analyzing the essential oil of $S$. africana within the same country of origin (such as Algeria), reported $\beta$-pinene
(12.78\%), 1,8-cineol (10.02\%), myrcene (6.94\%), curcumene (7.96\%), spathulenol (5.96\%), and $\beta$-eudesmol (14.58\%) as the main components.

Santolindiacetylene (28.5\%), camphor (12.5\%), myrcene (5.6\%), and $\beta$-phellandrene (5.4\%) were the main constituents identified in the essential oil of $S$. canescens from Spain, obtained by HD [51]. Other compounds found in a good amount were allo- 


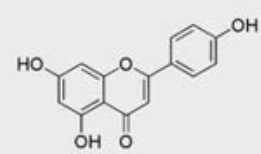

3

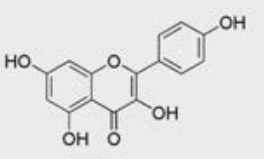

7<smiles>COc1ccc(-c2ccc(O)cc2O)c(O)c1</smiles><smiles>Oc1ccc(-c2ccc(O)c(O)c2)c(O)c1</smiles>

$\begin{array}{ll}5 & R=H \\ 6 & R=G 10\end{array}$

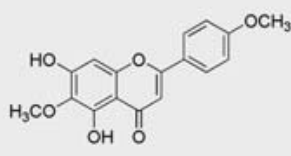

8

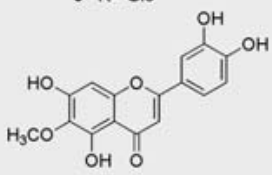

9

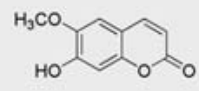

10

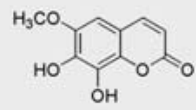

11

- Fig. 2 Chemical structures of flavonoids 3-9 and coumaris 10-11 from S. pinnata.

aromadendrene (4.4\%), $\beta$-caryophyllene (4.1\%), borneol (4.0\%), $\alpha$-terpineol (3.5\%), and germacrene D (3.0\%). A previous study reported camphor as the main constituent of the essential oil of S. canescens, followed by 1,8-cineole, $\beta$-pinene, myrcene, sabinene, ar-curcumene, and $\beta$-eudesmol [45].

A total of 41 compounds were identified in the essential oil from the flower heads of S. rosmarinifolia from Romania, which were rich in oxygenated monoterpenes and oxygenated sesquiterpenes. $\beta$-Eudesmol (13.5\%), 1,8-cineole (12.9\%), camphor $(8.0 \%)$, borneol (5.1\%), ar-curcumene (4.8\%), terpinen-4-ol $(4.5 \%)$, and spathulenol $(4.4 \%)$ were the main constituents [52]. In an evaluation of the seasonal variation of the essential oil from the aerial parts of $S$. rosmarinifolia subsp. rosmarinifolia collected in Spain, $\beta$-phellandrene (14.4-27.6\%), $\beta$-pinene (17.0-26.5\%), limonene (2.7-5.2\%), and myrcene (0.3-15.3\%) were identified as the main constituents [53]. Moreover, it was found that the oil concentration showed a positive correlation with precipitation and a negative correlation with temperature. Specifically, the monoterpenes 1,8-cineole, limonene, and $\beta$-phellandrene correlated negatively with temperature, while capillene showed a positive correlation with precipitation. The other compounds did not show any manifest trend.

The aerial parts of S. pinnata collected in Tuscany (Italy) were characterized by the presence of seven flavonoids, namely, apigenin (3), chrysoeriol (4), luteolin (5), luteolin-7-glucoside (6), kaempferol (7), pectolinarigenin (8), and nepetin (9), and two coumarins, namely, scopoletin (10) and fraxetin (11) $(\triangleright$ Table 3 and Fig. 2) [6]. One new [1 $1 \alpha, 10 \beta$-epoxy-7 $\alpha \mathrm{H}$-germacr-4(15)-ene$2 \beta 5 \alpha, 6 \beta$-triol) (12)] and four known germacrane derivatives

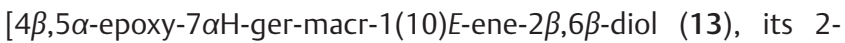
acetate $14,7 \alpha$ Hgermacra-1(10)E,4(15)-diene- $2 \beta, 5 \alpha, 6 \beta$-triol (15), and its 2-acetate 16] were isolated from the aerial parts of $S$. pinnata subsp. neapolitana ( $\bullet$ Fig. 3 ) [54]. Compounds 13-16 have also been previously isolated from $S$. chamaecyparissus [25].

Three eudesmane sesquiterpenoids, $(1 R, 2 R, 5 R, 6 R, 7 S, 10 S)$-eudesma-4(15)-en-1,2,6-triol (17), (1R,2S,6R,7S,10S)-1,2,6-trihy-

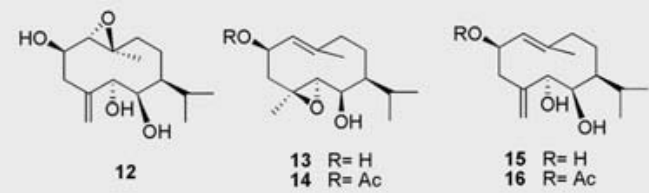

- Fig. 3 Chemical structures of compounds 12-16.

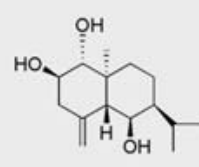

17

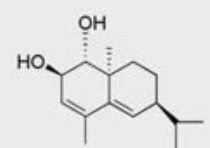

19
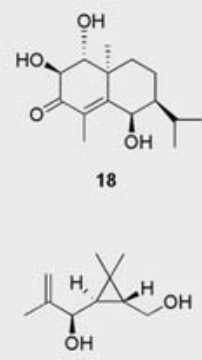

20
- Fig. 4 Chemical structures of eudesmane sesquiterpenes 17-20 from $S$. insularis.

droxyeudesma-4-en-3-one (18), and $(1 R, 2 R, 7 S, 10 S)$-eudesma3,5-dien-1,2-diol (19), and the trans-chrysanthemyl monoterpenoid $(2 R, 3 R, 4 R)$-5-chrysanthemen-1,4-diol (20) have been isolated from the acetone extract of the defatted aerial parts of $S$. insularis from Italy ( $\mathbf{F i g . 4 ) ~ [ 3 ] . ~ S p e c i f i c a l l y , ~ t h e ~ a c e t o n e ~ e x t r a c t ~}$ was subjected to MPLC, affording two fractions that were further purified by HPLC.

A new monocyclic sesquiterpenic alcohol, elegansidiol (21), was isolated from the hexane extract of S. elegans ( $\bullet$ Fig. 5) [55]. 
From the aerial parts of $S$. chamaecyparissus subsp. squarrosa, collected in Sierra Nevada (Granada, Spain), four new sesquiterpenes, (4E,9Z)-6 $\beta$-acetoxy- $7 \alpha \mathrm{H}$-germacra-4,9-diene-l $\alpha, 2 \beta$-diol (22), (E)$6 \beta$-acetoxy-7 $\alpha$ Hgermacra-4,10(14)-diene- $\alpha, 2 \beta$-diol (23), (E)-6 $\beta$ acetoxy-7 $\alpha \mathrm{H}$-germacra-I(10),4-diene- $2 \beta$-ol (24), and $6 \beta$-acetoxy$5 \beta \mathrm{H}, 7 \alpha \mathrm{H}, 10 \beta$ Me-eudesm-4(15)-ene- $1 \alpha, 2 \beta$-diol (25) (• Fig. 5), were isolated [23]. The air-dried aerial parts of $S$. chamaecyparissus subsp. squarrosa were subjected to maceration by using $t$-butylmethyl ether as the solvent. A portion was defatted by precipitation in methanol at a low temperature. The defatted extract was subjected to column chromatography by using the mixture hexane-t-butylmethyl ether-EtOAc of increasing polarity as the eluent. New sesquiterpenes with a germacrane skeleton were isolated from the aerial parts of S. rosmarinifolia subsp. canescens [24]. The air-dried and powdered aerial parts of S. rosmarinifolia subsp. canescens, collected in Sierra Nevada (Granada, Spain), were extracted by the Soxhlet apparatus with hexane as the solvent. After removal of the solvent, the obtained residue was dissolved in chloroform. This mixture was added to methanol at $50^{\circ} \mathrm{C}$, allowed to cool to room temperature, then further cooled at $-10^{\circ} \mathrm{C}$ for $24 \mathrm{~h}$, yielding an insoluble fraction that was purified by column chromatography. The six main fractions collected were subjected to repeated separations by silica gel chromatography. The isolated compounds were (E)-7 $\alpha \mathrm{H}$-germacra-1(10),4(15)-diene-5 $\alpha, 6 \beta$-diol (26), $4 \beta, 5 \alpha$ epoxy-7 $\alpha \mathrm{H}$-germacr-10(14)-ene- $1 \beta, 6 \beta$-diol (27), (E)-6 $\alpha, 11$-dihydroxy-7 $\alpha \mathrm{H}$-germacra-4,10(14)-dien-1-one (28), (E)-7 $\alpha \mathrm{H}$-germacra-4,10(14)-diene- $1 \alpha, 6 \alpha, 11$-triol (29), (E)-7 $\alpha \mathrm{H}$-germacra4,10(14)-diene-1 $\beta, 6 \alpha, 11$-triol (30), (E)-7 $\alpha \mathrm{H}$-germacra-4,10(14)diene-1 $\alpha, 6 \beta$-diol (31), (1E,4E)-7 $\alpha \mathrm{H}$-germacra-1(10),4-dien-6 $\beta$-ol (32), and shiromool (33) ( $\triangleright$ Fig. 6). The aerial parts of S. insularis collected in Italy were sequentially extracted with $n$-hexane and acetone. The acetone extract was subjected to MPLC to afford, after purification by HPLC, 11 germacrane sesquiterpenes, four of which are new [2]. The new compounds are $(2 R, 5 R, 6 R, 7 S)$-germacra-1(10)E,4(15)-dien-5-hydroperoxy-2,6-diol (34), (2R,5R,6R, $7 S)$-germacra-1(10)E,4(15)-dien-5-hydroperoxy-2,6-diol-2-acetate (35), (1R,2R,4S,5S,6R,7S)-4,5-epoxygermacra-9Z-en-1,2,6triol (36), and (3R,6R,7S)-3,6-dihydroxygermacra-4(5)E,10(14)-dien-1-one (37) ( $\triangleright$ Fig. 7).

\section{Biological Properties}

Several Santolina species have been studied for their biological properties. The antimicrobial, antifungal, antiviral, and anti-inflammatory activities were mainly investigated. However, most of the literature data concern in vitro studies ( $\triangleright$ Table 4 ). Few studies are performed by using in vivo models.

\section{Antibacterial and antifungal}

In the last years, the search for new antibiotics has accelerated. There are two main reasons. Nearly every antibiotic used today is based on a discovery of more than 30 years ago. At the same time, multidrug-resistant bacteria have been observed with increasing frequency over the past several decades. Many plants have been used for their antimicrobial properties due to their constituents, including phenolic compounds and essential oils. The essential oil of several Santolina species was subjected to investigations

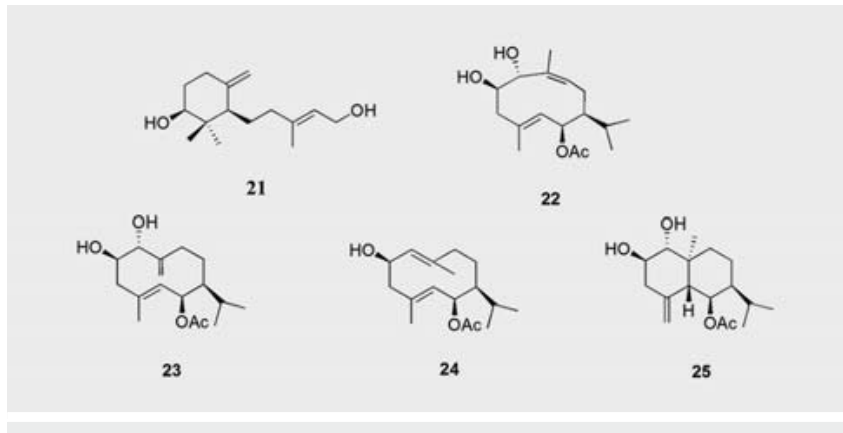

Fig. 5 Chemical structures of compounds 21-25.

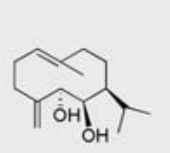

26

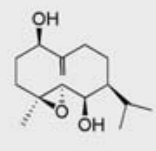

27

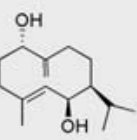

31

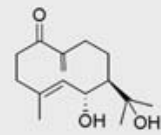

28

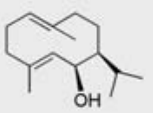

32

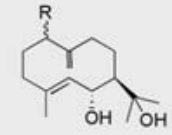

$29 \mathrm{R}=\alpha-\mathrm{OH}$
$30 \mathrm{R}=\beta-\mathrm{OH}$

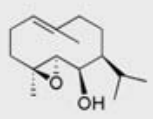

33
- Fig. 6 Chemical structures of sesquiterpenes with a germacrane skeleton (26-33) isolated from S. rosmarinifolia subsp. canescens.

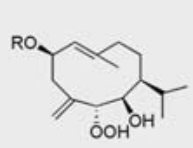

$34 \begin{aligned} & R=H \\ & R=A C\end{aligned}$

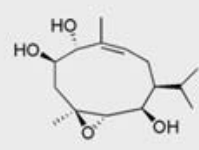

36
- Fig. 7 Chemical structures of germacrane sesquiterpenes 34-36 isolated from $S$. insularis.

against different gram-positive bacteria, gram-negative bacteria, and fungi. The essential oil of S. corsica was tested in vitro for its antimicrobial properties by using the agar diffusion method against two gram-positive bacteria (Staphylococcus aureus and Listeria innocua) and four gram-negative bacteria (Campylobacter jejuni, Enterobacter aerogenes, Escherichia coli, and Pseudomonas aeruginosa) [8]. The essential oil inhibited the growth of $S$. aureus $(14.7 \mathrm{~mm})$ and, especially, the growth of C. jejuni $(39 \mathrm{~mm})$. A moderate antimicrobial activity was found against $L$. innocua 
- Table 4 Investigated bioactivities of Santolina species.

\begin{tabular}{|c|c|c|c|c|}
\hline Activity & Species & Test/bacteria/fungi/yeast/cell line & Sample & Ref. \\
\hline \multirow[t]{7}{*}{ Anti-inflammatory } & S. chamaecyparissus & PLA2-induced mouse paw edema & methanol extract & {$[11]$} \\
\hline & S. chamaecyparissus & carrageenan paw edema in rats & chloroform extract & {$[59]$} \\
\hline & S. chamaecyparissus & inhibition of PLA1 & methanol extract & {$[60]$} \\
\hline & S. insularis & croton oil-induced dermatitis in mouse ears & methanol extract & {$[5]$} \\
\hline & S. oblongifolia & $\begin{array}{l}\text { adjuvant carrageenan-induced inflammation, } \\
\text { ACII, model using Wistar male rats }\end{array}$ & $\begin{array}{l}\text { hexane, dichloromethane, } \\
\text { ethyl acetate, and metha- } \\
\text { nol extracts }\end{array}$ & {$[61]$} \\
\hline & S. oblongifolia & $\begin{array}{l}\text { ionophore-stimulated mouse peritoneal } \\
\text { macrophages }\end{array}$ & $\begin{array}{l}\text { hexane, dichloromethane, } \\
\text { ethyl acetate, and metha- } \\
\text { nol extracts }\end{array}$ & {$[62]$} \\
\hline & S. viscosa & NF- $\kappa B, I L-6, I L-8$, TNF- $\alpha$, PGE2 & $\begin{array}{l}\text { petroleum ether, ethyl ace- } \\
\text { tate, and methanol extracts }\end{array}$ & {$[64]$} \\
\hline \multirow[t]{7}{*}{ Antimicrobial } & S. africana & $\begin{array}{l}\text { A. flavus, A. niger, B. subtilis, C. albicans, E. coli, } \\
\text { E. faecalis, K. pneumonia, P. aeruginosa, P. vulgaris, } \\
\text { S. aureus, S. epidermidis }\end{array}$ & essential oil & [49] \\
\hline & S. chamaecyparissus & $\begin{array}{l}\text { B. bronchiseptica, C. albicans, E. coli, K. pneumonia, } \\
\text { M. luteus, P. aeruginosa, E. faecalis, S. aureus, } \\
\text { S. cerevisiae, S. epidermis }\end{array}$ & essential oil & {$[38]$} \\
\hline & S. chamaecyparissus & $\begin{array}{l}\text { A. fumigatus, C. albicans, C. freundii, E. floccosum, } \\
\text { E. coli, E. faecalis, M. canis, S. aureus, S. brevicaulis, } \\
\text { S. dimidiatum, P. aeruginosa, P. mirabilis, T. rubrum }\end{array}$ & essential oil & {$[35]$} \\
\hline & S. chamaecyparissus & C. albicans & essential oil & [9] \\
\hline & S. corsica & $\begin{array}{l}\text { C. jejuni, E. aerogenes, E. coli, L. innocua, } \\
\text { P. aeruginosa, S. aureus }\end{array}$ & essential oil & $\begin{array}{l}{[8,} \\
56]\end{array}$ \\
\hline & S. etrusca & S. ferax & $\begin{array}{l}\text { aqueous and methanol } \\
\text { extracts }\end{array}$ & {$[57]$} \\
\hline & S. rosmarinifolia & B. cereus, C. albicans, E. coli, S. aureus, S. Iutea & essential oil & {$[51]$} \\
\hline \multirow[t]{2}{*}{ Antiviral } & S. insularis & HSV-1 and HSV-2 & essential oil & {$[10]$} \\
\hline & S. insularis & HSV-1 & $\begin{array}{l}\text { liposome-incorporated } \\
\text { essential oil }\end{array}$ & {$[58]$} \\
\hline Cytotoxic & S. chamaecyparissus & $\begin{array}{l}\text { MCF-7, HCT116, A549, HepG2 human tumor } \\
\text { cell lines }\end{array}$ & essential oil & {$[65]$} \\
\hline Hepatoprotective & S. canescens & $\begin{array}{l}\text { carbon tetrachloride-induced hepatotoxicity } \\
\text { in Wistar rats model }\end{array}$ & essential oil & {$[66]$} \\
\hline
\end{tabular}

(9.5 mm), while the growth of E. aerogenes, E. coli, and P. aeruginosa was not inhibited. In order to identify the compounds responsible for this activity, fractions were tested. An interesting antimicrobial activity of a lyratol-rich fraction (84\%) was observed against C. jejuni $(90 \mathrm{~mm})$ and S. aureus (19 mm), suggesting that lyratol could be the main responsive of the antimicrobial properties of S. corsica.

A bactericidal action was recognized for $S$. corsica essential oil, which rapidly inhibited the cell viability of S. aureus (MIC of $5 \mathrm{mg} /$ $\mathrm{mL}$ ) [56]. After treatment with the MIC value and 8 times the MIC value of S. corsica essential oil, no lytic effect was observed. The cell wall and the cytoplasmic membrane are involved in the activity of S. corsica essential oil. In fact, invaginations of the plasmic membrane with thickenings of the cell wall and aggregations of the cytoplasmic contents were detected in S. aureus treated with the $S$. corsica essential oil at the MIC value.
A study reported on the antimicrobial activity of the essential oil S. rosmarinifolia flower heads [51]. The essential oil showed good activity against the gram-positive bacteria Bacillus cereus, S. aureus, and Sarcina lutea, and a minor activity against the fungus Candida albicans and the gram-negative E. coli. The strongest activity was reported against S. aureus with MIC and MBC values of 0.3 and $0.6 \mu \mathrm{L} / \mathrm{mL}$, respectively. The antimicrobial effects of S. chamaecyparissus essential oil were studied in different works. The oil of S. chamaecyparissus from Algeria was tested by the agar disc diffusion method against the gram-negative bacteria Bordetella bronchiseptica, E. coli, Klebsiella pneumonia, and P. aeruginosa, the gram-positive bacteria Enterococcus faecalis, Micrococcus luteus, S. aureus, and Staphylococcus epidermis, the fungus C. albicans, and the yeast Saccharomyces cerevisiae [38]. The essential oil strongly inhibited the growth of $C$. albicans and $K$. pneumonia. Interesting results were also obtained with the essential oil of S. chamaecyparissus collected in Tunisia [35]. This essential oil 
was investigated against seven strains of fungi (three dermatophytes, Epidermophyton floccosum, Microsporum canis, and Trichophyton rubrum; one opportunist pathogenic yeast, C. albicans; and three hyphamycetes, Aspergillus fumigatus, Scopulariopsis brevicaulis, and Scytalidium dimidiatum), two gram-positive bacteria (E. faecalis and S. aureus), and four-gram negative bacteria (E. coli, P. aeruginosa, Proteus mirabilis, and Citrobacter freundii) [35]. Except for $C$. albicans, the inhibition of the fungi growth rate varied in the range of $73.0-89.25 \%$ in the presence of $500 \mu \mathrm{g} / \mathrm{mL} \mathrm{S}$. chamaecyparissus essential oil. E. floccosum was the most sensitive to the flower head essential oil (89.25\%). The MIC values varied in the range from 500 to $1000 \mu \mathrm{g} / \mathrm{mL}$. Generally, S. chamaecyparissus oil showed antibacterial activity against all bacterial strains with MIC values in the range of $0.625-10 \mu \mathrm{g} / \mathrm{mL}$. In the agar diffusion method, the gram-positive bacterium $E$. faecalis (inhibition zone of $26 \mathrm{~mm}$ ) was the most susceptible microorganism to the action of the flower head essential oil. S. chamaecyparissus essential oil from India showed potent antifungal activity against $C$. albicans, with MICs from 62.5 to $125 \mu \mathrm{g} / \mathrm{mL}$ of broth [9]. Clotrimazole was used as a positive control. The drug showed an MIC value of $3.125-6.25 \mu \mathrm{g} / \mathrm{mL}$. When the mixture of $S$. chamaecyparissus oil and clotrimazole at the D4 dilution $(31.25$ and $3.125 \mu \mathrm{g} / \mathrm{mL}$ for the essential oil and clotrimazole, respectively) was tested, the MIC was effective in controlling C. albicans. The S. chamaecyparissus oil was also effective in vivo in controlling experimental vaginal candidiasis. This activity was comparable to that of clotrimazole. The essential oil of S. africana demonstrated activity against several microorganisms (standard strains Bacillus subtilis, E. faecalis, E. coli, P. aereginosa, Proteus vulgaris, S. aureus, and S. epidermidis, clinical strain K. pneumonia, and fungi Aspergillus flavus, Aspergillus niger, and C. albicans), with an inhibition zone medium diameter in a concentration-dependent manner [49]. The inhibitory activity was in the range of $7.0-20.15 \mathrm{~mm}$. The highest inhibition zone was found for $B$. subtilis at $8 \times 10^{3} \mu \mathrm{g} / \mathrm{mL}$. Saprolegniosis is a very common mycosis of animals that live in fresh and mesohaline water. The aqueous and methanol extracts of $S$. etrusca aerial parts were studied for their potential antimicrobial properties against Saprolegnia ferax [57]. The most active extract was the aqueous extract that exhibited an MIC value of $2 \%$. The methanol extract showed an MIC of $1 \%$.

Overall, studies on Santolina species as antimicrobial agents are of interest. Some of the essential oils obtained by Santolina species showed comparable activity to widely used drugs such as clotrimazole. For this reason, an urgent need of animal and human studies to determine their effectiveness in whole-organism systems, with particular reference to their potential toxicity, are required in order to clarify if these phytochemicals could be used in therapy or in lead compounds for the development of more efficacy and a safe antimicrobial product. Moreover, in addition to tests and classic bacteriostatic and bactericidal activities, it is also important to investigate extracts and pure compounds against alternative bacterial targets, such as host-directed targets, pathogenesis, and virulence.

\section{Antiviral activity}

The only Santolina species that was investigated for its antiviral activity was S. insularis. In particular, the essential oil of S. insularis was studied against HSV-1 and HSV-2 [10]. Infections by HSV-1 and HSV-2 are among the most common viral infections in humans. When HSV-1 and HSV-2 were exposed to the S. insularis essential oil for $1 \mathrm{~h}$ at $37^{\circ} \mathrm{C}$, a concentration-dependent inhibition of plaque formation was observed. A $50 \%$ inhibition was observed at 0.88 and $0.7 \mu \mathrm{g} / \mathrm{mL}$ for HSV-1 and HSV-2, respectively. The inactivation of both HSV-1 and HSV-2 depends on the length of exposure to $S$. insularis essential oil. In fact, a higher inhibition was detected when HSV-1 and HSV-2 were preincubated for $2 \mathrm{~h}$ at the same temperature of $37{ }^{\circ} \mathrm{C}(50 \%$ inhibition at 0.31 and $0.26 \mu \mathrm{g} /$ $\mathrm{mL}$ for HSV-1 and HSV-2, respectively). Moreover, the inactivation of HSV-1 was more efficient than HSV-2 when viruses were preincubated for $15 \mathrm{~min}$ before adsorption (50\% inhibition at 6.39 and $7.66 \mu \mathrm{g} / \mathrm{mL}$ for HSV-1 and HSV-2, respectively). In attachment tests, a $50 \%$ inhibition was demonstrated in respect to the untreated controls at concentrations $>30 \mu \mathrm{g} / \mathrm{mL}$ for both viruses. These values were higher than those obtained with the controls of viruses preincubated (for $2 \mathrm{~h}$ at $4{ }^{\circ} \mathrm{C}$ ) in the presence of the same concentrations of $S$. insularis oil, showing that attachment was not affected and the activity was primarily due to the direct effects on the virion. Overall, obtained results indicated that $S$. insularis essential oil is effective in inactivating HSV-1 and HSV-2. The inactivation is time and temperature independent. No differences were detected in the plaque reduction assays when cells were treated with the oil before virus adsorption.

The way in which $S$. insularis essential oil acts is unique in that no natural products are able concomitantly to inactivate the virus and inhibit cell-to-cell virus spread. Moreover, it is of interest that the $\mathrm{IC}_{50}$ values of $\mathrm{S}$. insularis essential oil against both HSV-1 and HSV-2 is comparable to those reported for approved drugs for the treatment of HSV infections, such as acyclovir and ganciclovir. Further studies are necessary to investigate the effect of the essential oil in animal models infected with HSV, and to isolate phytochemicals responsible for the antiviral activity.

Successively, Valenti et al. [58] prepared, characterized, and investigated the in vitro antiviral activity of liposome-incorporated S. insularis essential oil (multilamellar and unilamellar vesicles obtained from hydrogenated soya phosphatydilcholine and cholesterol). The anti-HSV-1 properties were studied by plaque and yield reduction tests. The $S$. insularis essential oil could be incorporated in high amounts in the prepared liposomes. The essential oil inactivated HSV-1. This activity is mainly due to direct virucidal effects. The $S$. insularis oil was more active than the liposome-incorporated essential oil. The $\mathrm{ED}_{50}$ values were considerably lower when cells were preincubated with the oil before the adsorption of the virus. These data suggested an intracellular mechanism for the activity of the oil of $S$. insularis. Importantly, liposomal S. insularis essential oil was nontoxic in the range of concentrations tested in the study.

Despite the recent progress made in immunization and drug development, many infections represent a serious health problem since there are no vaccines and efficient antiviral therapies, which are often surrounded by the generation of viral mutants. Consequently, the search for new antiviral drugs is a hot topic of research. Taking into account that plants are an excellent source of phytochemicals with a broad range of bioactivity, including antiviral, the research of natural compounds with this property will be 
enhanced. In this context, S. insularis represents a promising species that requires much attention.

\section{Anti-inflammatory activity}

Studies were carried out in order to validate the traditional uses of some Santolina species as anti-inflammatory agents. Some extracts of S. chamaecyparissus were the object of study for evaluation of their potential anti-inflammatory activity. Giner et al. [59] proved the anti-inflammatory properties of the chloroform extract of S. chamaecyparissus against carrageenan paw edema in rats. The anti-inflammatory activity of the methanol extract of S. chamaecyparissus was demonstrated in different experimental models [60]. In particular, this extract inhibited PLA1 activity in vitro at $1 \mathrm{mg} / \mathrm{mL}$. No lipoxygenase inhibitory effects were found.

Sala et al. [11] reported the activity of the methanol extract of S. chamaecyparissus against PLA2-induced mouse paw edema. An inhibition of the edema with percentages of 55 and $60 \%$ at 30 and $60 \mathrm{~min}$, respectively, was evidenced. This activity is comparable to the reference drug cyproheptadine with 65 and $66 \%$ inhibition at 30 and $60 \mathrm{~min}$, respectively. After fractionation by using solvents with different polarities (hexane, dichloromethane, ethyl acetate, and butanol), only the dichloromethane extract was active against the PLA2 in vitro test with a percentage of inhibition of $48 \%$. Moreover, it was shown to reduce the edema induced by $12-0$-tetradecanoylphorbol-13-acetate and arachidonic acid in a multidose test.

Fractionation of the dichloromethane extract gave eight fractions, three of which were active with inhibition percentages against PLA2 activity ranging from 47 to $62 \%$. From the active fractions, four purified sesquiterpenes and one flavone, spathulenol, (7S)-4 $\beta, 5 \alpha$-epoxygermacrl(10)E-en-2 $\beta, 6$-diol, (7S)-germacra4(15)Z,9dien-1 $\alpha, 2 \beta, 5 \alpha, 6 \beta$-tetraol, (7S)-germacra-1(10)E,4(15)dien-2 $\beta, 5 \alpha, 6 \beta$-triol, and nepetin, were isolated. Only the fraction from which nepetin was isolated maintained an inhibition range of $50 \%$, including the flavonoid with a percentage of $52 \%$.

Hexane, dichloromethane, ethyl acetate, and methanol extracts obtained from the air-dried aerial parts of S. oblongifolia by means of a Soxhlet extractor were investigated for their potential anti-inflammatory activity by using the adjuvant carrageenan-induced inflammation (ACII) model using Wistar male rats [61]. Elevated serum $\mathrm{Cu}$ levels and decreased serum $\mathrm{Zn}$ levels associated with the development of arthritis in ACII immunizing Wistar rats were demonstrated.

Administration of S. oblongifolia extracts significantly prevented the development of ACII in Wistar rats, and they were more active than the positive control indomethacin in the chronic phase of the experiment. The most interesting extract was the ethyl acetate extract, which possesses potent activity against these parameters of chronic inflammation [62]. The flavonoids apigenin (3), luteolin (5), and quercetin were isolated from this extract and tested together with the coumarins aesculetin, herniarin, scopoletin (10), and scopolin [7]. The isolated coumarins showed a marked activity as inhibitors of eicosanoid release from ionophore-stimulated mouse peritoneal macrophages. A significant inhibitory activity of eicosanoid release from ionophore-stimulated mouse peritoneal macrophages was found. Scopoletin, aesculetin, scopolin, and herniarin showed $\mathrm{IC}_{50}$ values of 5,11 ,
77 , and $84 \mu \mathrm{mol}$, respectively. In the LTC4-release test, only aesculetin exhibited a significant effect, with an $\mathrm{IC}_{50}$ value of $18 \mu \mathrm{mol}$. Scopolin showed an inhibition rate of $55 \%$ at the highest concentration, while herniarin and scopoletin demonstrated no significant effects on LTC4 release.

Apigenin, luteolin, quercetin, herniarin, scopoletin, scopolin, and aesculetin, isolated from S. oblongifolia, have been investigated for their anti-inflammatory activity [63]. All phytochemicals influenced the response to thromboxane $B(2)$ release in a dosedependent way, and with percentages of inhibition being slightly lower than ibuprofen, used as a reference drug. Among all investigated classes of phytochemicals, flavonoids and coumarin exerted the most potent activity, probably due to their ability to inhibit arachidonic acid metabolism. Several researches evidenced that flavonoids are safe alternatives to combat several inflammatory reactions. However, recently, certain side effects related to the use of these compounds were reported [64]. Even though it is widely accepted that natural products are safe, evidence suggests that upon clinical use, these drugs are never being seen without risk. In this context, Santolina-derived products could represent an alternative, but only after investigation of their nontoxic character.

The aerial parts of Santolina viscosa collected in Spain, together with 60 other plant species, were subjected to a sequential extraction by petroleum ether, ethyl acetate, and methanol [65]. The obtained extracts were studied for their potential anti-inflammatory activity targeting NF- $\kappa$ B and other proinflammatory mediators (IL-6, IL-8, TNF- $\alpha$ ) or PGE2 in monocytes. A weak inhibitory activity was found against NF- $\kappa B$, while in tests against the cytokines. a number of species, including $S$. viscosa, inhibited TNF- $\alpha$ $(10 \mu \mathrm{g} / \mathrm{mL})$.

The methanol extract of $S$. insularis leaves was studied for its chemical profile and topical anti-inflammatory activity by using croton oil-induced dermatitis in the mouse ear [5]. Six flavonoids, namely, cirsimaritin, hispidulin, luteolin, luteolin 7-O- $\beta$-D-glucopyranoside, nepetin, and rhamnocitrin, and one new xanthone, (E)-3-(6-[(E)-3-hydroxy-3-oxo-1-propenyl]-9-oxo-9Hxanthen-2yl)-2-propenoic acid, were isolated and tested. All compounds were able to inhibit croton oil-induced ear edema. The most active, after topical application, was luteolin $\left(0.3 \mu \mathrm{mol} / \mathrm{cm}^{2}\right)$, that led to a $62 \%$ reduction of edema, while indomethacin $(0.3 \mu \mathrm{mol} /$ $\mathrm{cm}^{2}$ ), used as a reference compound, led to a $59 \%$ reduction of edema. Cirsimaritin, hispidulin, nepetin, and rhamnocitrin showed lower anti-inflammatory activity compared to luteolin. Taking into account that all these flavonoids are methoxylated, the lack of one of the free hydroxyl groups determined a decrease of activity. After topical application, xanthone showed only a $20 \%$ reduction of edema.

\section{Cytotoxic activity}

Few studies reported the cytotoxic activity of Santolina species. The essential oil of S. chamaecyparissus was investigated against MCF-7, HCT116, A549, and HepG2 cancer cell lines [66]. The highest cytotoxic activity was found against HepG2 cancer cells.

Eleven germacrane sesquiterpenes were isolated from the acetone extract of the aerial parts of $S$. insularis and tested for their potential cytotoxic activity against the human colon carcinoma 
cell line Caco-2 [2]. The highest activity was found for compound 36 , with an $\mathrm{IC}_{50}$ value of $1.1 \mu \mathrm{M}$. These results encourage research towards the study of the antiproliferative activity of other Santolina species and isolated constituents.

\section{Other properties}

A study was conducted to investigate possible protective effects of the essential oil of $S$. canescens and its main constituent santolindiacetylene on carbon tetrachloride $\left(\mathrm{CCl}_{4}\right)$-induced hepatotoxicity in an experimental Wistar rat model [67]. Determination of GPT serum levels is a useful indicator of hepatocellular damage. In fact, in the presence of damage to the cell membrane, some cytoplasmatic enzymes such as GPT are released into the bloodstream. In the employed model, a dose of carbon tetrachloride produced a rise in GPT levels and lipid peroxides in the liver. The protective effects of $S$. canescens essential oil and santolindiacetylene were demonstrated by their ability to prevent this increase. In both groups treated with the essential oil or santolindiacetylene, levels of GPT were clearly lower than in the group treated only with $\mathrm{CCl}_{4}$. Moreover, no significant differences between the results obtained with $S$. canescens and santolindiacetylene and those obtained with silymarin (known as a hepatoprotective agent, used as a positive control) were found. The interest in the essential oils as biopesticides is growing because the long-term uses of synthetic insecticides lead to the accumulation of residues and produce adverse effects on human health and ecosystems. In this context, the biocidal properties of S. chamaecyparissus were investigated [68]. Specifically, the objects of the study were the nematicidal (Meloidogyne javanica), ixodicidal (Hyalomma lusitanicum), insect antifeedant (Leptinotarsa decemlineata, Myzus persicae, Spodoptera littoralis, and Rhopalosiphum padi), and phytotoxic effects (Lolium perenne and Lactuca sativa). The essential oil of S. chamaecyparissus demonstrated strong antifeedant effects against $R$. padi and $H$. lusitanicum while showing moderate activity against L. decemlineata and S. littoralis. Moreover, moderate phytotoxic activity against the leaf growth of $L$. perenne was found.

\section{Conclusions and Perspectives}

This review summarized the uses in traditional medicine and the main phytochemicals and biological properties of species of the genus Santolina.

Some Santolina species are traditionally used in different countries for their antispasmodic, digestive, analgesic, anti-inflammatory, antiseptic, stimulant, and antimicrobial properties. To a certain extent, some traditional uses have been scientifically validated and supported by biological studies. In particular, results obtained on the antimicrobial effects of Santolina species showed a good correlation with the reported traditional uses. However, according to literature information, only a few species of this genus have been extensively investigated for the evaluation of their chemical profile. Among isolated constituents, terpenes (mainly germacrane and eudesmane derivatives) are the most representative compounds. Several new sesquiterpenes have been identified in S. insularis, S. chamaecyparissus subsp. squarrosa, S. pinnata subsp. neapolitana, S. rosmarinifolia subsp. canescens, and S. insu- laris. These constituents may be considered chemotaxonomic markers of the genus. However, phytochemical investigations on more Santolina species are required in order to confirm the possibility to use these molecules as taxonomic markers.

Although phytochemical and biological studies on Santolina species have received considerable interest, some gaps are still noteworthy. Firstly, most of the studies are aimed at evaluating the nonpolar constituents of Santolina species and not at characterizing the polar compounds, such as flavonoids, identified in S. insularis and S. pinnata. Secondly, studies mainly focused on four Santolina species, S. chamaecyparissus, S. insularis, S. corsica, and S. oblongifolia. Therefore, a comprehensive investigation of other species is necessary. Thirdly, various biological activities of the extracts and pure compounds were mainly investigated by using in vitro tests and less were carried out by in vivo models. Therefore, there are few reported data focused on toxicity, side effects, and clinical efficiency. Fourthly, the few pharmacological studies are still insufficient to determine the effects and validate the uses of Santolina species in traditional medicine. Therefore, more detailed studies are required 1) to investigate Santolina species that have never been chemically and biologically studied, 2) to analyze the potential toxicity of Santolina extracts and/or essential oils, 3) to identify the pharmacokinetics and pharmacodynamics of bioactive compounds isolated from the most promising extracts/ essential oils, and 4) to develop systems to increase the efficacy and safety of Santolina-derived products.

\section{Conflict of Interest}

The authors declare no conflicts of interest.

\section{References}

[1] Derbesy M, Touche J, Zokd A. The essential oil of Santolina chamaecyparissus L. J Essent Oil Res 1989; 1: 269-275

[2] Appendino G, Aviello G, Ballero M, Borrelli F, Fattorusso E, Petrucci F, Santelia FU, Taglialatela-Scafati O. Cytotoxic germacrane sesquiterpenes from the aerial parts of Santolina insularis. J Nat Prod 2005; 68: 853-857

[3] Fattorusso E, Santelia FU, Appendino G, Ballero M, Taglialatela-Scafati O. Polyoxygenated eudesmanes and trans-chrysanthemanes from the aerial parts of Santolina insularis. J Nat Prod 2004; 67: 37-41

[4] De Pascual TJ, Bellido IS, González MS, Vicente S. Tetracyclic triterpenes and nerolidol derivatives from Santolina oblongifolia. Phytochemistry 1985; 25: 185-190

[5] Cottiglia F, Casu L, Bonsignore L, Casu M, Floris C, Sosa S, Altinier G, Della Loggia R. Topical anti-inflammatory activity of flavonoids and a new xanthone from Santolina insularis. Z Naturforsch C 2005; 60: 63-66

[6] Flamini G, Ghelli GC, Pistelli L, Morelli I. Phenolic compounds from Santolina pinnata. Planta Med 1994; 60: 97

[7] Silván AM, Abad M], Bermejo P, Sollhuber M, Villar A. Antiinflammatory activity of coumarins from Santolina oblongifolia. J Nat Prod 1996; 59: 1183-1185

[8] Liu K, Rossi PG, Ferrari B, Berti L, Casanova J, Tomi F. Composition, irregular terpenoids, chemical variability and antibacterial activity of the essential oil from Santolina corsica Jordan et Fourr. Phytochemistry 2007; 68: 1698-1705

[9] Suresh B, Sriram S, Dhanaraj SA, Elango K, Chinnaswamy K. Anticandidal activity of Santolina chamaecyparissus volatile oil. J Ethnopharmacol 1997; 55: 151-159 
[10] De Logu A, Loy G, Pellerano ML, Bonsignore L, Schivo ML. Inactivation of HSV-1 and HSV-2 and prevention of cell-to-cell virus spread by Santolina insularis essential oil. Antiviral Res 2000; 48: 177-185

[11] Sala A, Recio MC, Giner RM, Máñez S, Ríos JL. Anti-phospholipase A2 and anti-inflammatory activity of Santolina chamaecyparissus. Life Sci 2000; 66: PL35-PL40

[12] Villar A, Giner RM, Rios JL. Chemical composition of Santolina chamaecyparissus subsp. squarrosa essential oil. J Nat Prod 1986; 49: 1143-1145

[13] Giner RM, Rios JL, Villar A. Pharmacological study of Santolina chamaecyparissus. Phytother Res 1988; 12: 37-41

[14] Yoganarasimhan SN. Medicinal Plants of India-Tamilnadu, vol II. Bangalore: Cyber Media; 2000: 276

[15] Calvo MI, Cavero RY. Medicinal plants used for ophthalmological problems in Navarra (Spain). J Ethnopharmacol 2016; 190: 212-218

[16] Akerreta S, Cavero RY, López V, Calvo MI. Analyzing factors that influence the folk use and phytonomy of 18 medicinal plants in Navarra. J Ethnobiol Ethnomed 2007; 3: 16-34

[17] Savo V, Giulia C, Maria GP, David R. Folk phytotherapy of the Amalfi Coast (Campania, Southern Italy). J Ethnopharmacol 2011; 135: 376392

[18] Loi MC, Poli F, Sacchetti G, Selenu MB, Ballero M. Ethnopharmacology of Ogliastra (Villagrande Strisaili, Sardinia, Italy). Fitoterapia 2004; 75: 277295

[19] Ballero M, Fresu I. Piante officinali impiegate in fitoterapia nel territorio del Marganai (Sardegna sud-occidentale). Fitoterapia 1991; 62: 524531

[20] Poli F, Bonsignore L, Loy G, Sacchetti G, Ballero M. Comparison between the essential oils of Santolina insularis (Genn. ex Fiori) Arrigoni and Santolina corsica Jord. et Fourr. from the island of Sardinia (Italy). J Ethnopharmacol 1997; 56: 201-208

[21] Guarrera PM, Forti G, Marignoli S. Ethnobotanical and ethnomedicinal uses of plants in the district of Acquapendente (Latium, Central Italy). J Ethnopharmacol 2005; 96: 429-444

[22] Novais MH, Santos I, Mendes S, Pinto-Gomes C. Studies on pharmaceutical ethnobotany in Arrabida Natural Park (Portugal). J Ethnopharmacol 2004; 93: 183-195

[23] Barrero AF, Alvarez-Manzaneda R, Quilez JF, Mar Herrador M. Sesquiterpenes from Santolina chamaecyparissus subsp. squarrosa. Phytochemistry 1998; 48: 807-813

[24] Barrero AF, Herrador MM, Quilez JF, Alvarez-Manzaneda R, Portal D, Gavin JA, Gravalos DG, Simmonds MS, Blaney WM. Bioactive sesquiterpenes from Santolina rosmarinifolia subsp. canescens. A conformational analysis of the germacrane ring. Phytochemistry 1999; 51: 529-541

[25] Alberto Marco J, Sanz-Cervera JF, Carda M, Lex J. Oxygenated germacranes from Santolina chamaecyparissus. Phytochemistry 1993; 34: 1549

[26] Sanz JF, Garcia-Sarrion A, Alberto Marco J. Germacrane derivatives from Santolina chamaecyparissus. Phytochemistry 1991; 30: 3339-3342

[27] Maqua MP, Vines ACG, Caballero E, Grande MC, Medarde M, Bellido IS. Components from Santolina rosmarinifolia, subspecies rosmarinifolia and canescens. Phytochemistry 1988; 27: 3664

[28] Bohlmann F, Zdero C. Polyacetylenverbindungen, 152. Die Acetylenverbindungen aus Santolina chamaecyparissus L. Chem Ber 1968; 101: 2062

[29] Lam J, Bildsoe H, Christensen LP, Thomasen T. Chemical constituents of Santolina chamaecyparissus. Acta Chem Scand 1989; 43: 799-802

[30] Perez-Alonso M], Negueruela V. Essential oil components of Santolina chamaecyparissus L. Flav Fragr J 1992; 3: 37-41

[31] Giner RM, Manez S, Rios JL. Seasonal variations in the essential oil of Santolina chamaecyparissus L. Sci Pharm 1993; 61: 169-173

[32] Lawrence M. Santolina Oil. In: Lawrence BM, ed. Essential Oils, 19921994. Card Stream, IL USA: Allured Publ. Corp.; 1995: 57-59

[33] Vernin G. Volatile constituents of the essential oil of Santolina chamaecyparissus L. J Essent Oil Res 1991; 3: 49-53
[34] Demirci B, Ozek T, Baser KHC. Chemical composition of Santolina chamaecyparissus L. essential oil. J Essent Oil Res 2000; 12: 625-627

[35] Salah-Fatnassi KBH, Hassayoun F, Cheraif I, Khan S, Jannet HB, Hammami M, Aouni M, Harzallah-Skhiri F. Chemical composition, antibacterial and antifungal activities of flowerhead and root essential oils of Santolina chamaecyparissus L., growing wild in Tunisia. Saudi J Biol Sci 2017; 24: 875-882

[36] Garg SN, Gupta D, Mehta VK, Kumar S. Volatile constituents of the essential oil of Santolina chamaecyparissus Linn, from the Southern hills of India. J Essent Oil Res 2001; 13: 234-235

[37] Khubeiz M], Mansour G. In vitro antifungal, antimicrobial properties and chemical composition of Santolina chamaecyparissus essential oil in Syria. Int J Toxicol Pharmacol Res 2016; 8: 372-378

[38] Djeddi S, Djebile K, Hadjbourega G, Achour Z, Argyropoulou C, Skaltsa $\mathrm{H}$. In vitro antimicrobial properties and chemical composition of Santolina chamaecyparissus essential oil from Algeria. Nat Prod Commun 2012; 7: 937-940

[39] Tognolini M, Barocelli E, Ballabeni V, Bruni R, Bianchi A, Chiavarini M Impicciatore M. Comparative screening of plant essential oils: phenylpropanoid moiety as basic core for antiplatelet activity. Life Sci 2006; 78: $1419-1432$

[40] Grosso C, Figueiredo AC, Burillo J, Mainar AM, Urieta JS, Barroso JG, Coelho JA, Palavra AM. Supercritical fluid extraction of the volatile oil from Santolina chamaecyparissus. J Sep Sci 2009; 32: 3215-3222

[41] Rossi PG, Panighi ], Luciani A, de Rocca Serra D, Maury J, Gonny M, Muselli A, Bolla JM, Berti L. Antibacterial action of essential oils from Corsica. J Ess Oil Res 2007; 19: 176-182

[42] Cherchi G, Deidda D, De Gioannis B, Marongiu B, Pompei R, Porcedda S Extraction of Santolina insularis essential oil by supercritical carbon dioxide: influence of some process parameters and biological activity. Flavour Fragr ] 2001; 16: 35-43

[43] Gnavi G, Bertea CM, Usai M, Maffei ME. Comparative characterization of Santolina insularis chemotypes by essential oil composition, 5SrRNA-NTS sequencing and EcoRV RFLP-PCR. Phytochemistry 2010; 71: 930-936

[44] Ferrari B, Tomi F, Richomme P, Casanova J. Two new irregular acyclic ses quiterpenes aldehydes from Santolina corsica essential oil. Magn Reson Chem 2005; 43: 73-74

[45] Pérez-Alonso M], Velasco Negueruela A. The essential oils of four Santolina species. Flav Fragr J 1988; 3: 37-42

[46] Senatore F, De Feo V. Composition of the essential oil of Santolina neapolitana Jordan et Fourr. Flav Fragr J 1994; 9: 77-79

[47] Flamini G, Bertoli A, Taglioli V, Cioni PL, Morelli I, Spinelli G. Composition of the essential oil of Santolina ligustica. J Essent Oil Res 1999; 11: 6-8

[48] Flamini G, Cioni PL. Seasonal variation of the chemical constituents of the essential oil of Santolina etrusca from Italy. Chem Biodiv 2007; 4: 1008-1019

[49] Derouiche K, Zellagui A, Gherraf N, Bousetla A, Dehimat L, Rhouati S. Chemical composition, antimicrobial and antioxidant activities of the essential oils of Santolina africana flowers, endemic in Algeria. J BioSci Biotech 2013; 2: 201-206

[50] Zaiter L, Benayache F, Beghidja N, Figueredo G, Chalard P, Chalchat JC, Marchioni E, Benayache S. Essential oils of Santolina africana Jord. \& Fourr. and Santolina chamaecyparissus L. J Essent Oil Bear PI 2015; 18: 1338-1342

[51] Mateos JPC, Martínez A, Navarro MC, Utrilla MP, Jiménez J. Multiple head space extraction of volatiles from Santolina canescens Lagasca during its growth cycle. J Essent Oil Res 2001; 13: 170-173

[52] Ioannou E, Poiata A, Hancianu M, Tzakou O. Chemical composition and in vitro antimicrobial activity of the essential oils of flower heads and leaves of Santolina rosmarinifolia L. from Romania. Nat Prod Res 2007; 21: $18-23$ 
[53] Palá-Paúl ], Pérez-Alonso M], Velasco-Negueruela A, Palá-Paúl R, Sanz J, Conejero F. Seasonal variation in chemical constituents of Santolina rosmarinifolia L. subsp. rosmarinifolia. Biochem Syst Ecol 2001; 29: 663-672

[54] Kisiel W, Dawid-Pać R, Grabarczyk H, Nowak G. Germacrane derivatives from Santolina pinnata subsp. neapolitana. Z Naturforsch C 2003; 58: 793-796

[55] Barrero AF, Alvarez-Manzaneda E], Mar Herrador M, Alvarez-Manzaneda R, Quilez J, Chahboun R, Linares P, Rivas A. The first route toward oxygenated monocarbocyclic terpenoids: synthesis of elegansidiol, a new sesquiterpene from Santolina elegans. Tetrahedron Lett 1999; 40: 8273-8276

[56] Guinoiseau E, Luciani A, Rossi PG, Quilichini Y, Ternengo S, Bradesi P, Berti L. Cellular effects induced by Inula graveolens and Santolina corsica essential oils on Staphylococcus aureus. Eur J Clin Microbiol Infect Dis 2010; 29: 873-879

[57] Macchioni F, Perrucci S, Flamini G, Cioni PL, Morelli I. Antimycotic activity against Saprolegnia ferax of extracts of Artemisia verlotorum and Santolina etrusca. Phytother Res 1999; 13: 242-244

[58] Valenti D, De Logu A, Loy G, Sinico C, Bonsignore L, Cottiglia F, Garau D, Fadda AM. Liposome-incorporated Santolina insularis essential oil: preparation, characterization and in vitro antiviral activity. J Liposome Res 2001; 11: 73-90

[59] Giner R, Rios JL, Villar A. Pharmacological study of Santolina chamaecyparissus. I. Acute toxicity, antiinflammatory and antiulcer activity. Planta Med 1986; 52: 540-541

[60] Cuéllar M], Giner RM, Recio MC, Just MJ, Máñez S, Cerdá S, Ríos JL. Screening of antiinflammatory medicinal plants used in traditional medicine against skin diseases. Phytother Res 1998; 12: 18-23
[61] Silván AM, Abad M], Bermejo P, Villar A. Effect of Santolina oblongifolia on ACll-immunized animals. Inflammopharmacology 1997; 5: 351-361

[62] Silván AM, Abad M], Bermejo P, Villar A, Söllhuber M. Anti-inflammatory activity of three flavonoids from Santolina oblongifolia. Phytother Res 1996; 10: S65-S66

[63] Silván AM, Abad M], Bermejo P, Villar A. Effects of compounds extracted from Santolina oblongifolia on TXB(2) release in human platelets. Inflammopharmacology 1998; 6: 255-263

[64] Martinez SE, Davies NM, Reynolds JK. Toxicology and Safety of Flavonoids. In: Davies NM, Yáñez JA, eds. Flavonoid Pharmacokinetics: Methods of Analysis, preclinical and clinical Pharmacokinetics, Safety, and Toxicology. Hoboken, NJ, USA: John Wiley \& Sons, Inc.; 2012: 249-267

[65] Bremner P, Rivera D, Calzado MA, Obón C, Inocencio C, Beckwith C, Fiebich BL, Muñoz E, Heinrich M. Assessing medicinal plants from South-Eastern Spain for potential anti-inflammatory effects targeting nuclear factor-Kappa B and other pro-inflammatory mediators. J Ethnopharmacol 2009; 124: 295-305

[66] Elsharkawy ER. Anticancer effect and seasonal variation in oil constituents of Santolina chamaecyparissus. Chem Materials Res 2014; 6: 85-91

[67] Utrilla MP, Navarro MC, Jimenez J, Montilla MP, Martin A. Santolindiacetylene, a polyacetylene derivative isolated from the essential oil of Santolina canescens. J Nat Prod 1995; 58: 1749-1752

[68] de Elguea-Culebras GO, Sánchez-Vioque R, Berruga MI, Herraiz-Peñalver D, González-Coloma A, Andrés MF, Santana-Méridas O. Biocidal potential and chemical composition of industrial essential oils from Hyssopus officinalis, Lavandula $x$ intermedia var. super and Santolina chamaecyparissus. Chem Biodivers 2018; 15: e1700313. doi:10.1002/cbdv. 201700313 